\title{
Socio-economic vulnerability of coastal communities in southern Thailand: the development of adaptation strategies
}

\author{
P. Willroth ${ }^{1}$, F. Massmann ${ }^{2}$, R. Wehrhahn ${ }^{2}$, and J. Revilla Diez ${ }^{1}$ \\ ${ }^{1}$ Institute for Economic and Cultural Geography, Leibniz University of Hannover, Germany \\ ${ }^{2}$ Department of Geography, Christian-Albrechts-University Kiel, Germany
}

Correspondence to: P. Willroth (willroth@wigeo.uni-hannover.de)

Received: 23 December 2011 - Accepted: 28 June 2012 - Published: 22 August 2012

\begin{abstract}
The tsunami of December 2004 impacted large areas of Thailand's coastline and caused severe human and economic losses. The recovery period revealed differences in the vulnerabilities of communities affected. An understanding of the causal factors of vulnerability is crucial for minimising the negative effects of future threats and developing adaptive capacities. This paper analyses the vulnerabilities and the development of adaptation strategies in the booming tourist area of Khao Lak and in the predominantly fishing and agricultural area of Ban Nam Khem through a comprehensive vulnerability framework. The results show that social networks played a crucial role in coping with the disaster. Social cohesion is important for strengthening the community and developing successful adaptation strategies. The development of tourism and the turning away from traditional activities have a significant positive influence on the income situation, but create a dependency on a single business sector. It could be shown that households generating their income in the tourism sector were vulnerable unless they had diversified their income previously. Income diversification decreased the vulnerability in the study areas. Adaptation strategies and processes developed in the aftermath clearly address these issues.
\end{abstract}

\section{Introduction}

The December 2004 Indian Ocean tsunami severely impacted coastal regions and highlighted their vulnerability to external shocks. Thailand was one of the most severely affected countries, with major damage occurring in the PhangNga province involving the loss of at least 4224 lives. Local livelihoods were seriously disrupted not only due to damage and destruction of houses and occupational assets, but also due to the impacts on natural resources and ecosystems (Thanawood et al., 2006). Tourist areas as well as entire fishing villages had to go through a recovery process which included initial relief measures directly after the event, the rebuilding of houses and the resumption of work. Now, seven years later, the affected communities can be considered to have fully recovered, although the situation for many people is not the same as it was before the tsunami. Interestingly, the recovery time of different groups of the affected population varied greatly according to various factors. During the recovery period and thereafter, adaptation strategies were developed on different levels to prepare for potential future disasters, and also to improve the living situation in general. The long period of time from the occurrence of the tsunami until the present offers a good opportunity to analyse the recovery process and the development of adaptive capacities.

The differences in recovery revealed the various vulnerabilities of communities exposed. An understanding of the causal factors of vulnerability is crucial to reducing the impact of future events and building resilience. This study attempts to analyse the vulnerability of coastal communities in southern Thailand through the holistic vulnerability framework for coupled human-environment systems developed by Turner et al. (2003). We focus thereby on the dimension of resilience which is determined by the capacity to cope, adapt or recover from the effects of hazardous conditions (Smit and Wandel, 2006).

In the light of the severe impacts of the tsunami, we argue that it is essential to investigate the adaptation processes against the background of pre-tsunami vulnerability by assessing the vulnerabilities of communities affected. The development of future sustainable livelihoods is not possible 
without recognizing and understanding the social, economic and political factors contributing to vulnerability. The principle during the reconstruction period of "building back better" can thus be reviewed critically (Clinton, 2006). To tackle all these tasks, we applied a multi-method approach consisting of quantitative surveys and qualitative focus-group discussions.

\section{Theoretical framework}

The term vulnerability is used broadly due to its development in various disciplines. In the context of climate change and natural hazards, vulnerability is no longer applied exclusively to the technical hazard perspective. According to the conception that natural hazards do not become catastrophes until human lives are affected, the focus has shifted to the vulnerability of the society. Even in this limited field, there is no consensus definition of vulnerability and no consistent approach to its operationalisation (Yamin et al., 2005; Bohle and Glade, 2007).

According to Turner et al. (2003), "vulnerability is the degree to which a system, subsystem, or system component is likely to experience harm due to exposure to a hazard, either an exogenous perturbation or an endogenous stress or stressor". Therefore, vulnerability is a composition of multiple interacting factors emerging from the social, economic and environmental spheres of an exposure unit (Turner et al., 2003; Birkmann, 2006). It is widely agreed that the theoretical concept of vulnerability consists of the three dimensions exposure, susceptibility or sensitivity, and resilience or adaptive capacity (Clark et al., 2000; Cutter et al., 2003; Adger, 2006; Birkmann, 2006; Gallopín, 2006; Smit and Wandel, 2006). In the following explanations, we will refer to the interpretation of Turner et al. (2003) and speak of exposure, sensitivity and resilience.

Another widely agreed upon aspect is the complexity of vulnerability resulting from the dynamic interplay of the multidimensional factors on various scales (Adger, 2006). In order to emphasise this, the following example is provided: the ability to anticipate, withstand and recover from natural hazards is determined by access to different forms of capital, which is again determined by specific institutional and governance conditions. Those conditions build upon wider, historically embedded socio-political and economic processes (Wisner and Cannon, 2005). Within their meta-analysis, Zou and Wei (2010) identified driving factors for social vulnerability to coastal hazards in Southeast Asia, including population growth, migration to the coast, poorly planned urbanisation and tourism development, which lead to land-use changes and transformations of ecosystems. Those processes in turn also constitute the vulnerability of a system.

To give consideration to the complexity of vulnerability, this study applies the holistic vulnerability framework for coupled human-environment systems developed by Turner et al. (2003). By combining the three dimensions of vulnerability, it identifies and maps the interlinked factors contributing to vulnerability on different scales (Fig. 1).

Exposure identifies the system components (e.g. people, houses, infrastructure) that are at risk of being impacted upon by a certain stress factor. Exposure is thus defined as the degree to which a human group or ecosystem comes into contact with stresses (Clark et al., 2000). It is represented by the physical location of an exposure unit and certain characteristics of the build-up and natural environment (Pelling, 2003). In the context of the tsunami, this may be the distance to the shoreline or the height above sea level, but also the existence of protective vegetation. Sensitivity, the second dimension of vulnerability, relates to pre-existing human and environmental conditions which reflect the ability of the system to cope with the impacts of a hazard (in the following discussion, we use the term "sensitivity elements" for these conditions). According to Pelling (2003), sensitivity is a characteristic of the society and manifests itself in different livelihoods. Sensitivity is defined as the degree to which an exposure unit is affected by stresses (Clark et al., 2000). Resilience to natural hazards is the ability of a system to cope with or adapt to stresses without changes in its fundamental structure or function (Pelling, 2003; Kasperson et al., 2010). Accordingly, resilience is an expression of the strength of the human-environment system. The concept of resilience originates in ecological sciences (Holling, 2001; Berkes et al., 2003) and has been adopted and modified continuously by various disciplines. Resilience expresses itself in the capacities to cope and to adapt.

The terms coping and adaptation are often used to describe how communities deal with shocks and stresses. The ability to cope and adapt is strongly influenced by political and social power relations. Coping can be seen as a direct reaction to the impacts of a hazard on a society or community and comprises strategies and measures during or immediately after the event (Birkmann, 2011). Adaptation, however, is applied after the disaster and refers to medium- and long-term strategies that lead to change (Fig. 2; Miller et al., 2010; Birkmann, 2011). While coping with a flood could imply moving important items to a higher place or selling assets, adaptation in the same regard would mean building dykes or changing occupation.

The development of adaptation is based on the experience from the previous hazard, the pre-hazard setting and, additionally, the external input into the community from governmental or non-governmental agencies in terms of knowledge or financial support (Martin, 2010). In order to reduce the vulnerability and to adapt to future hazards, all factors contributing to a successful development of adaptation strategies in the community need to be taken into account (Wolfe, 2010). The ability to cope or to adapt differs according to social characteristics such as the financial situation or power relations. Therefore, there are various coping and adaptation constraints (Adger et al., 2009). Birkmann (2011) defined 


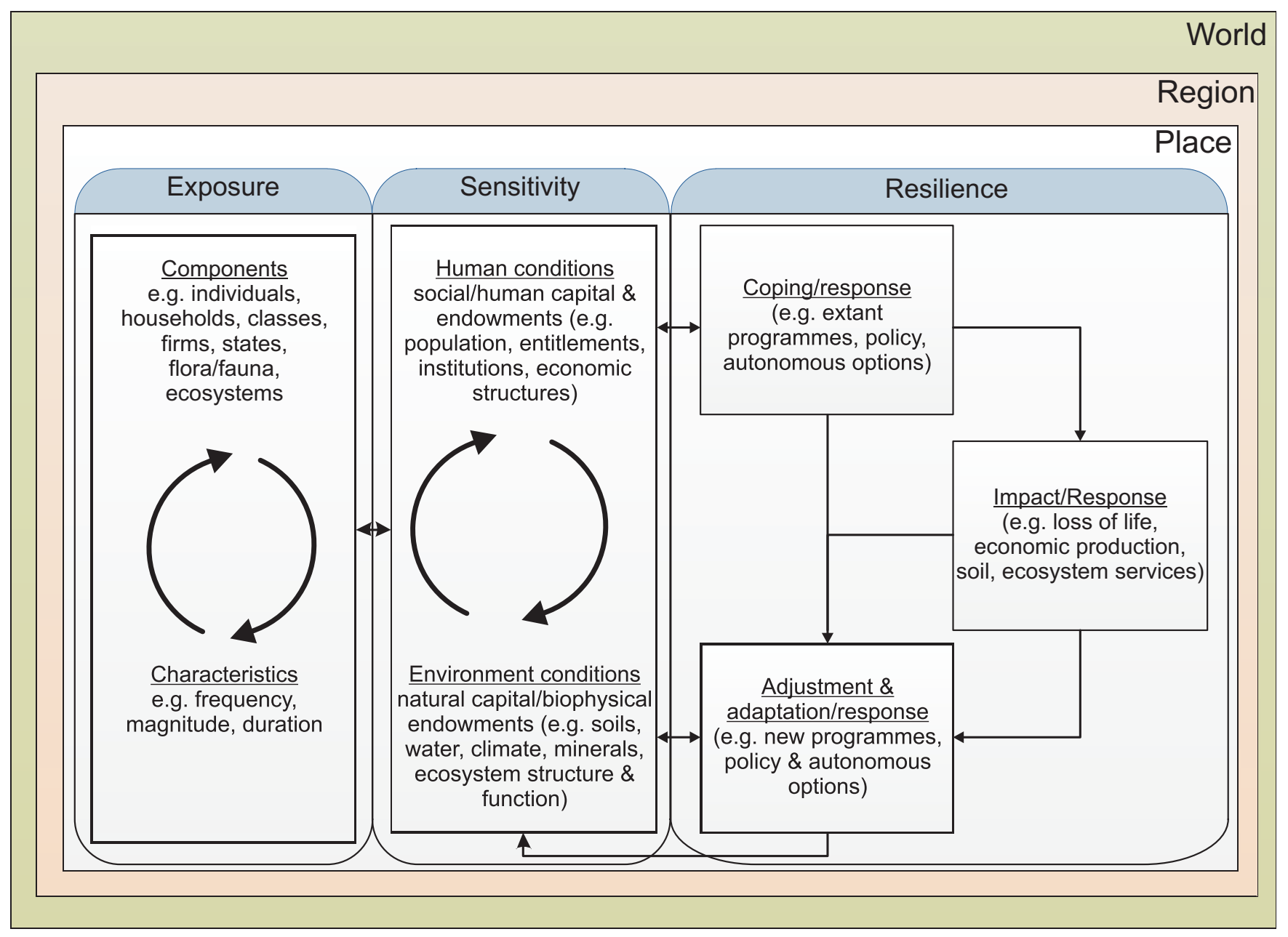

Fig. 1. Vulnerability framework (Based on Turner et al., 2003).

three different forms of limits of adaptation. First of all, there are physical limits, which means that the physical impacts of a hazard are too severe to react to. Secondly, financial limits determine the response and adjustments to impacts in terms of costs. And finally, political, social and institutional limits determine the operation of political systems, social networks or institutional structures resulting in failure or inefficiency.

\section{Study area and methods}

The Phang-Nga province was the worst affected area in Thailand in terms of casualties and damage to buildings, infrastructure, property and natural resources (Vorlaufer, 2005; Bechteler et al., 2006). It is a rural province dominated by agriculture and fisheries. Agriculture contributes $46 \%$ of the gross provincial product (GPP), and fisheries another $9 \%$. Compared to Phuket, where the hotel and restaurant sector accounted for almost $40 \%$ of the GPP in the year 2008, the tourism development in Phang-Nga is still in the initial phase with a contribution of $2 \%$ of GPP (NESDB, 2011).
Located on the Andaman Coast of Phang-Nga, the two areas of Khao Lak and Ban Nam Khem were selected as representative study areas for investigation (Fig. 3). Khao Lak is a young tourism destination that nowadays focuses on topclass tourism and ecotourism in contrast to its busy neighbour Phuket, which is located approximately $100 \mathrm{~km}$ to the south and is characterised by mass tourism (Vorlaufer, 2005). The rapid tourism development since the 1990s has influenced the local population as well as the local ecosystems. Traditional activities such as small-scale fisheries and agriculture are decreasing, and tourism-related land-use change often leads to ecological degradation. Nevertheless, agricultural and fishing activities in Khao Lak still contribute significantly to the diversity of the area.

Ban Nam Khem is a fishing village, virtually untouched by tourism, which had around 4500 inhabitants prior to the tsunami. The village and its surroundings are located $5 \mathrm{~km}$ north of Khao Lak. Agricultural areas and aquaculture are dominant along the coastline. However, there are strong linkages between Ban Nam Khem and Khao Lak in terms of 


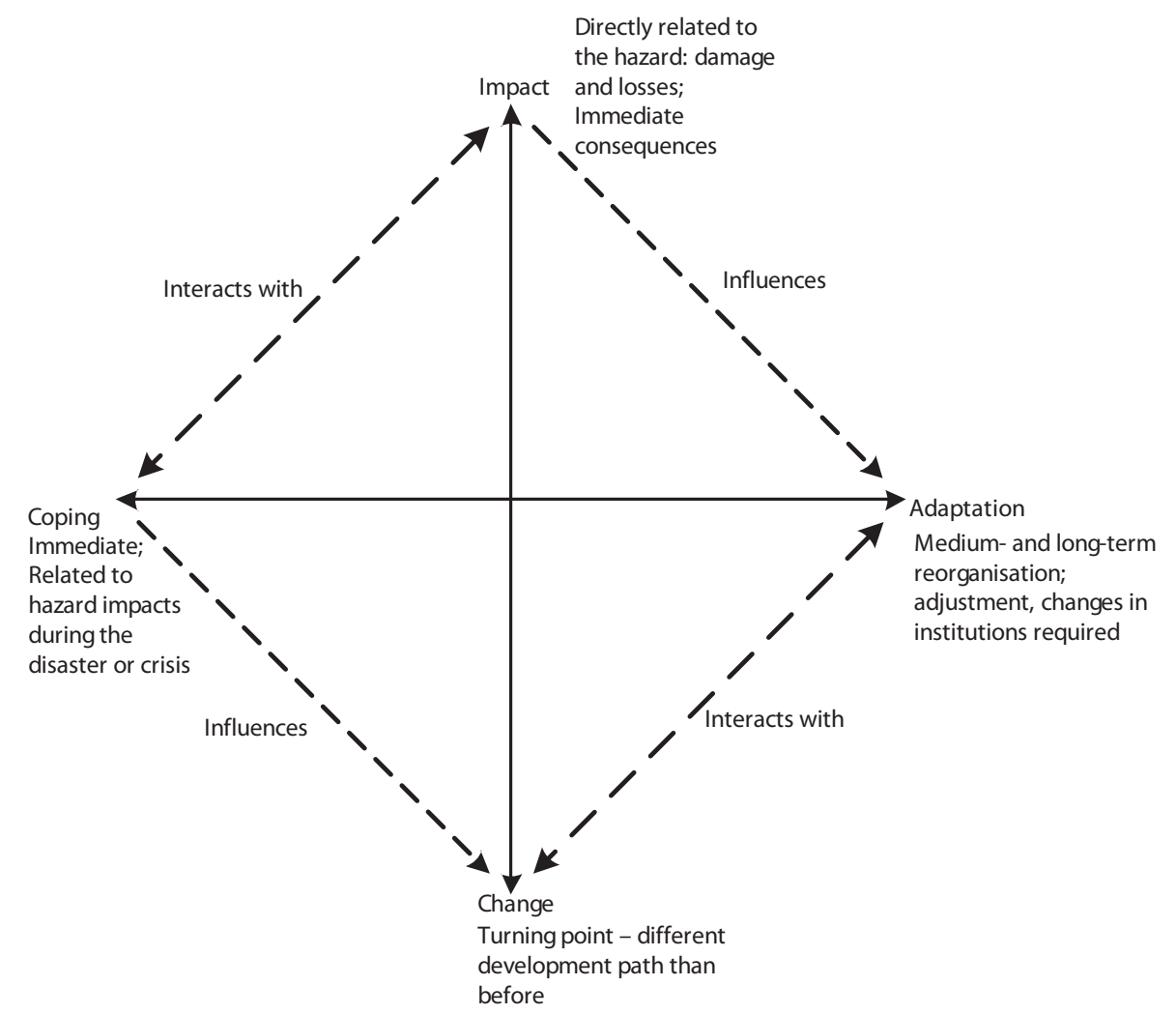

Fig. 2. Relation between coping, adaptation, impact and change (Based on Birkmann, 2011).

commuters working in the tourism sector (25\% of the working population in Ban Nam Khem) and other tourism-related demands such as the trade of local products (Willroth et al., 2011). The economic focus is clearly on fisheries, since more than half of the businesses can be assigned to this sector. The village has its own fishing harbour with both upstream and downstream industries.

The narrow coastal strip of both case study areas is densely populated compared to the hinterland and therefore very much exposed to tsunami hazards. The dimension of the tsunami inundation area depends on the coast's physical features as well as on the tsunami characteristics (Fig. 3). In Khao Lak, major parts of the tourism infrastructure, located along the beachline, were destroyed. Households on the exposed Pakarang Cape in the north of Khao Lak suffered most. Besides direct impacts, local people were affected indirectly from income losses and unemployment. The village of Ban Nam Khem was completely devastated by the waves due to its low-lying location at the seashore, and nearly all households were affected directly and indirectly (Römer et al., 2012) The communities of Ban Nam Khem and Khao Lak represent a perfect study area for identifying adaptation strategies and their effectiveness not only because of their exposure, but also due to their special socio-economic setting and the fact that each of them has a specific business sector dominating the community.
The study builds on a quantitative survey that investigated the socio-economic situation of the households, their experience from the tsunami and the subsequent recovery process that took around two years. It was part of the project from which the results in this paper arise and is the basis for the further qualitative studies (Willroth et al., 2011). The survey is based on a previous field mapping conducted in the area in order to gather basic information about households and companies, since no official and reliable statistics are available on the chosen regional scale. Based on these data, the sampling could be carried out, with the main survey covering around $6 \%$ of the households and $20 \%$ of the companies in the two study areas. From January to March 2009, 170 households and 103 companies were interviewed by the TRAIT project team (TRAIT Household and Company Survey). The participation rate was two-thirds of the households and companies approached. Households were sampled according to their location and their housing situation, which can be seen as one of the major influences leading to physical affectedness from a tsunami (Beyene, 1992; Smith and Ward, 1998). Companies were sampled according to their location and their business sector in order to provide a representative sample for the region's business structure. Further methodological details and results regarding the vulnerability situation and the recovery process can be found in Willroth et al. (2011); Römer et al. (2012). 


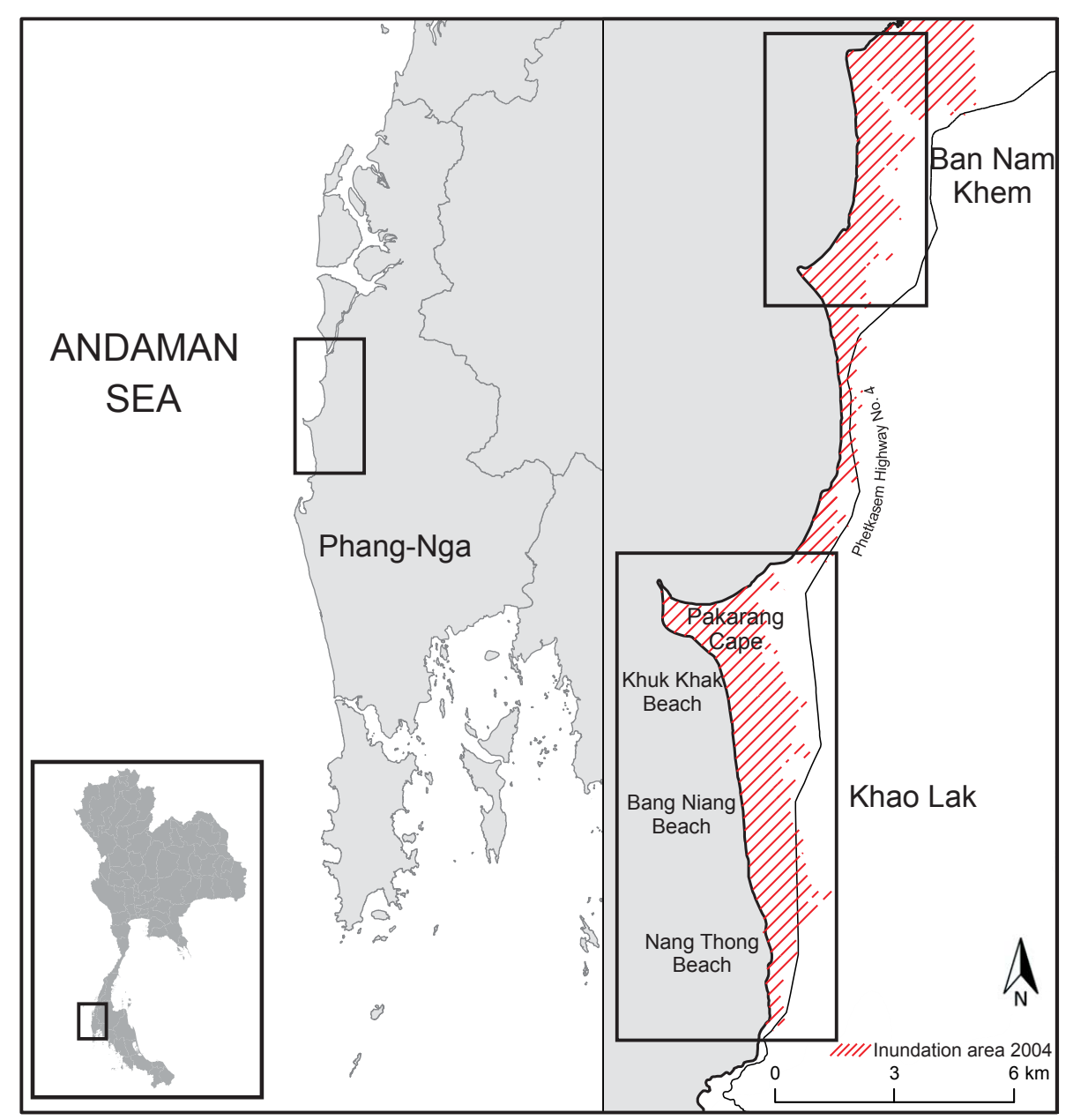

Fig. 3. Location of Ban Nam Khem and Khao Lak and the tsunami inundation area

The qualitative part of this paper is based on 7 focus groups and 32 individual interviews conducted in the period from August to October 2009. The main objectives were to identify (a) livelihood strategies of people exposed to the tsunami, (b) underlying factors influencing the vulnerability of the coastal communities, and (c) coping and adaptation strategies of the local population, NGOs and government. All interviewees were either local people working in the region or stakeholders from the tourism, agricultural or fisheries sectors. The composition of the focus groups was chosen to be homogeneous in terms of occupational affiliation but diverse within the occupational groups in order to achieve results as holistically as possible. The benefit of combining focus groups and individual interviews was an additional amount of information. In focus groups, collective opinions were revealed due to the dynamic and spontaneous communication, while in individual interviews, information was shared that otherwise would not emerge in a group setting (Kaplowitz, 2001).

The qualitative data were used with the aim of triangulating the information obtained from the quantitative surveys.
Here, the basic information on vulnerability and recovery derived from the quantitative approach builds the basis for applying qualitative methods as a means for identifying and analysing adaptation. Thus, focus groups and individual interviews are a crucial method within this study. The use of a mixed-method approach provides a more holistic view of socio-economic structures, individual actions and decisionmaking processes than single method approaches (Ziervogel et al., 2006; Miller et al., 2010).

\section{Vulnerability analysis: sensitivity elements and their influence on coping and adaptation capacities}

According to the theoretical framework, a vulnerability analysis needs to take into account factors contributing to the sensitivity of exposed elements in order to understand coping and adaptation processes. On the one hand, we identified relevant sensitivity elements by means of a structural equation model presented in an earlier paper published by this project (Willroth et al., 2011). The model was developed 
Table 1. Influence of sensitivity and resilience elements on the recovery capabilities of households (Willroth et al., 2011).

\begin{tabular}{lcc}
\hline & Rank $^{1}$ & Effect \\
\hline Dependence on external support from NGO & 1 & Reducing capability \\
Disruption of infrastructure & 2 & Reducing capability \\
Social network support recovery & 3 & Extending capability \\
Personal injuries & 3 & Reducing capability \\
Loss or reduction of income & 4 & Reducing capability \\
Dependence on external support from government & 5 & Reducing capability \\
Diversification of income & 6 & Extending capability \\
Education and income level & 6 & Extending capability \\
Income from tourism & Influence not significant \\
Amount of assets & Influence not significant \\
Damage level & Influence not significant \\
\hline
\end{tabular}

${ }^{1}$ Rank according to the influence on the recovery capability and the effect size of the element in the structural equation model

representing sensitivity and resilience elements following the "sustainable livelihood framework" provided by the DFID (2001). In order to represent a causal chain from the occurrence of damage to the final recovery, these elements were integrated. The outcome is presented in a simplified form in Table 1, ranked according to the influence on the recovery capability and the effect size. It could be found that a positive influence on the recovery capabilities of the households results from the availability of social networks, employmentrelated elements such as the diversification of income, and the income and education level. We also placed questions concerning coping and adaptation strategies within the qualitative interviews and focus groups and derived information about the underlying factors. We found the model's results to be verified. Accordingly, this paper focuses on four selected sensitivity elements that are crucial for the subsequent analysis of adaptation strategies: social networks, income diversification, income level and education. It can be seen that each sensitivity element contributes differently to the recovery process and is hence resilience-determining. For instance, no influence on the recovery of the households could be found resulting from the amount of pre-tsunami assets and the absolute amount of damage (Table 1). Therefore, these vulnerability elements were eliminated from further investigations.

Social networks and ties proved to have the strongest capability extending influence, increasing the possibility of a fast recovery from physical impacts due to monetary support or support in terms of goods from friends, family or neighbours. In many cases, people also suffered from mental problems due to loss of family members or injuries. The existing social networks helped people to cope with those mental problems by means of personal conversations and consolation (farmer, personal communication, Ban Nam Khem, 2009). Another beneficial factor concerning social networks relates to coping with income losses. Many interviewees indicated that, after losing their job as a result of the tsunami, family members, friends or neighbours offered them temporary work or helped them to find a new job (focus group agriculture, personal communication, Ban Nam Khem, 2009). Significant differences can be found between the two communities, since the tourism-oriented community of Khao Lak experiences a greater fluctuation of inhabitants, which expresses itself in a lower share of households benefiting from social networks as a form of recovery support. In vulnerability research, social networks are seen as important determinants for the coping and recovery process (Cutter et al., 2003; Thomalla et al., 2006).

Other sensitivity elements that influenced the reaction to income losses, and hence the recovery time, include the diverse natural environment and the diverse income situation. As mentioned earlier, both study areas are diverse in terms of land use. Despite the dominance of tourism in Khao Lak and fisheries in Ban Nam Khem, both areas are characterised by the coexistence of agriculture, fisheries, the construction business, tourism, commerce and other activities. Accordingly, the possibilities of finding income-substituting employment are quite good (focus group fishery, personal communication, Ban Nam Khem, 2009). Many interviewees stated that they had already diversified their income before the tsunami. Examples include the practise of a second job in another sector or subsistence activities such as backyard farming (focus group agriculture, focus group fishery, personal communication, Ban Nam Khem, 2009). There is consensus that diversification plays a crucial role in reducing vulnerability and building resilience (Blaikie et al., 1994; Bohle, 2001; Turner et al., 2003).

The influence of financial assets was modelled using indicators describing the dependency on external support from governmental and non-governmental agencies and the level of income achieved by the household. Categories concerning financial assets, and hence reflecting sensitivity elements, were also derived from the qualitative data. These indicators and categories show a clear picture leading to the conclusion 
that high-income households are less vulnerable and tend to recover faster than households depending on external support. A high income situation correlates with the possession of savings and insurance policies, which can absorb the negative effects of the tsunami. The income situation in Ban Nam Khem and Khao Lak shows that particularly the traditional activities (above all small-scale fishermen) have a low income level and consequently no savings or insurance. A special finding from the region reveals that the security of employment indicated by the possession of a formal working contract has no significant influence on the coping capacity, referring to the flexibility of the job market in that specific area of southern Thailand. The amount of long-term consumable assets shows no significant influence on household coping capacity. In contrast, the occupational assets such as boats, fishing gear or agricultural tools did influence the recovery time. When occupational assets were destroyed and not replaced immediately, this resulted in income losses and hence in an increased recovery time (focus group fishery, personal communication, Ban Nam Khem, 2009). Another crucial element is the death of household members, which can lead to an increased recovery time due to the mental impact on the family, the income losses and the financial expenses for the funeral ceremony.

A reducing influence on recovery time could also be found for the level of education of the working household members. A high level of education is often associated with a high social status and helps people to negotiate for external help (focus group tourism, personal communication, Khao Lak, 2009). Furthermore, educated people, mostly working in the tourism sector, are more flexible in terms of changing their job or adapting to new situations. Cutter et al. (2003) corroborate these findings and argue that educated persons can adapt more easily than other individuals to changes in economic circumstances, because they use assets more efficiently and exploit new income possibilities.

\section{Adaptation strategies of people exposed to tsunami risk and the role of influencing sensitivity elements}

Adaptation, as used in this study, is part of the vulnerability of Khao Lak and Ban Nam Khem and is thus influenced by sensitivity elements and the coping process as well as the experience from the impact of the previous hazard. In our understanding, the adaptation period started during - or rather directly after - the first aid phase and led to various trajectories. The adaptation strategies or processes were developed and initiated by households and companies and by governmental and non-governmental organisations, and are determined by the regions' socio-economic characteristics, the external inflow of knowledge and capital, and the differing impact levels of the tsunami. During the recovery period, Khao Lak had its advantage in a relatively high income and education level, but disadvantages compared to Ban Nam Khem in terms of the absence of social cohesion among the population and an overemphasised focus on the tourism sector (Massmann, 2010; Willroth et al., 2011).

\subsection{Ban Nam Khem}

As introduced before, Ban Nam Khem can be seen as a mostly fishing and agriculture-dominated area with ties to the regional centre of Khao Lak. Due to the proximity and the connections to the high income area of Khao Lak, household income is slightly higher than in the rest of the province. Nearly all households in the community suffered either from direct or indirect effects of the tsunami and very often experienced casualties. In the history of the community, various migrant groups moved to the area due to the economic upturn caused by the excavation of tin in the 1970s and the later turn to fishing businesses (Phaphavasit et al., 2009). Due to this inward migration situation, the villagers characterised their community before the tsunami as heterogeneous and as having a lack of community spirit (focus group fishery, personal communication, Ban Nam Khem, 2009).

This was changed by the experiences from the joint coping period which led to a new community spirit. This was mentioned by more than $12 \%$ of the households (TRAIT Household Survey). During the rebuilding phase, the households in Ban Nam Khem used their social networks significantly more often than households in the other study area to finance the restoration (TRAIT Household survey). Furthermore, the community organised several disaster risk management activities by itself and in cooperation with the government, such as regular tsunami drills, pick-up services for elderly people in the case of an emergency, or the planning of escape routes and tsunami shelters (TRAIT Household survey, focus group fishery, personal communication, Ban Nam Khem, 2009). Another adaptation process relating to the strengthening of social networks and community spirit is the common celebration of certain holidays, which are also used to carry out mitigation activities such as replanting mangroves. Compared to the positive effects on the community level, the tsunami destruction and the subsequent resettlements of families caused a segregation of neighbourhoods on the micro level, leading to a degradation of social networks in particular cases. Also, the disproportionate distribution of tsunami aid led to negative effects on social cohesion such as envy and mistrust (focus group agriculture, focus group fishery, personal communication, Ban Nam Khem, 2009). Nevertheless, seven years after the tsunami, the community seems stable and shows no outward migration (TRAIT Household Survey; focus group fishery, personal communication, Ban Nam Khem, 2009; Massmann, 2010).

Villagers often commented on the "second tsunami of external aid" in the community (TRAIT Household Survey; focus group fishery, personal communication, Ban Nam Khem, 2009). The tsunami destroyed the majority of fishing boats which were the occupational backbone of the community. 
For that reason, the community was the focus of national and international donors, with the consequence of overcompensation of destroyed fishing boats and gear with more and better equipment, which eventually led to overfishing, and in the long term forced several fishermen to change their occupation mostly to the service sector in nearby Khao Lak (focus group fishery, personal communication, Ban Nam Khem, 2009; Segschneider and Krause, 2008). Overfishing as a future threat for the community has been amplified by large fishing trawlers operating illegally in coastal waters since a few years after the tsunami. Local fishermen lack the negotiating power and financial resources to intervene and are suffering from this development. This negative development has resulted in a rethinking of traditional income possibilities.

Fishermen, and also farmers, argue that their village and the surrounding area has a potential for tourism development. To create new and higher income possibilities and to diversify the occupational landscape accordingly, the community of Ban Nam Khem started to implement tourism projects (focus group fishery, personal communication, Ban Nam Khem, 2009). Since the coastline is not yet occupied by hotels and resorts, there is huge potential for community-based projects. Furthermore, the positive experience with pre-tsunami income diversification has resulted in the increased practise of part-time jobs such as backyard farming, small-scale fishing or other activities. In keeping with this development, many NGOs implemented programs to strengthen local livelihoods in terms of promoting alternative sources of income, such as the cultivation of hydroponic crops or handicrafts (focus group agriculture, personal communication, Ban Nam Khem, 2009). This simultaneously boosts the skills of local people.

\subsection{Khao Lak}

When evaluating the adaptation strategies and processes developed in the area of Khao Lak, the past development needs to be considered. The development of Khao Lak into an international tourism destination started in the early 1990s and continued constantly until the tsunami struck in 2004 (Calgaro and Lloyd, 2008). Similarly to other developed tourism areas in Southeast Asia, Khao Lak started as a backpacker destination in the mid-1990s, mostly with smallscale businesses operated by locals (Calgaro, 2005). Facing a continuous growth in the following years, Khao Lak reached its peak in terms of the number of rooms available in 2004. It is by far the most important tourism destination in Phang-Nga and can be described as a lighthouse for development. Before the tsunami, the rapid development of tourism activities in Khao Lak was comparable with the rise of mass tourism in Phuket. Several international chains opened resorts, and some were still under construction when the tsunami struck (hotel owner, personal communication, Khao Lak, 2009). Before that, traditional agriculture and fishing activities were the main occupation of the local population. Due to the severe devastation along the coastline, several new opportunities for future development opened up (Nidhiprabha, 2007; Willroth, 2012).

The tsunami can be seen as a turning point regarding the economic development of Khao Lak. The impact initiated a strategic discussion among the business owners in terms of future development goals. While one group has tried to maintain the previous business strategy of masstourism-oriented growth, the other group can be described as supporting a more moderate development of the area. The moderate group, mainly local business owners, developed a unique strategy in order to tackle the weaknesses of the previous growth path. They concentrated on returning guests and on a sustainable tourism development (hotel owner, personal communication, Khao Lak, 2009). As a unique selling point, they focused on natural assets which the region has to offer regarding a nature-oriented and up-scale strategy (focus group tourism, personal communication, Khao Lak, 2009). For this purpose, the regional business owners enforced provincial regulations, such as building codes preventing buildings from being constructed directly on the coastline or high buildings within 100 metres of the shore, in order to protect the appearance of an untouched beach front, but also as a tsunami mitigation measure (Calgaro and Lloyd, 2008). The expansion of the number of businesses is not planned as a densification of the already existing resorts, but rather as a spatial spreading along the northern and southern coastline in order to maintain a nature-oriented image (focus group tourism, personal communication, Khao Lak, 2009). As a result, this attracts higher-income customer groups, in particular from Scandinavia and Central Europe who have supported the constant increase in value addition of this business sector in the Phang-Nga province, which led to an increase in the revenue per visitor of around $20 \%$ between 2004 and 2007. This is well above average compared to the national figures, which show an increase of only $4.5 \%$ (TAT, 2005a,b, 2007a,b, 2009a,b). This upturn in revenue per tourist should lead to an increase of household income level in the area.

Alongside the advantages of the new tourism development strategy, negative aspects must also be addressed. The analysis of the economic setting of the households shows that a stronger focus on tourism decreases the likelihood of a diversified income structure, which is determined by the higher income level in the tourism sector compared to other (traditional) activities. An extreme form of replacement of traditional forms of land use by tourism is the occupation of land, which can be illustrated by the example of Pakarang Cape, a peninsula in the northern part of Khao Lak. Before the tsunami, the peninsula was populated by a traditional fishing village with 60 households. In Thailand, rural households rarely possess a land title for the area in which their houses are built (Segschneider and Krause, 2008; focus group fishery, personal communication, Khao Lak, 2009). Accordingly, none of the inhabitants of Pakarang Cape had a legal land status. The tsunami completely devastated the fishing village, and the lack of land titles meant that their 
return and the rebuilding of their houses was prohibited by the government in this case. The fishermen and their families were resettled $2 \mathrm{~km}$ inland. As a result, they now need to commute to their fishing boats and spend time and money on a daily basis. Furthermore, they report the necessity of extra security guards for the fishing gear which cannot be left unattended. In addition, the relocated villagers stated that, in many cases, neighbourhoods and even family relations and networks were destroyed by the resettlement (focus group fishery, personal communication, Khao Lak, 2009). Nowadays, the former fishing village and its surroundings are occupied by resorts, which cause social conflicts. Furthermore, this development is amplified by the fact that new workforces are migrating to the area due to the increased income level and the higher demand in labour triggered by the booming tourism business.

\section{Discussion and conclusion}

The results presented in this paper provide an insight into the vulnerability and adaptation processes as well as into the potential development paths of coastal communities in southern Thailand in the context of the 2004 tsunami. We used the vulnerability framework for coupled human-environment systems (Turner et al., 2003) to identify and analyse the underlying factors of vulnerability and their contribution to the development of adaptation strategies and processes. Complementary to Birkmann (2011), we found that the development of adaptation strategies is amongst others driven by the impact of the hazard as well as by the strengths or weaknesses of sensitivity elements. Accordingly, a special focus was placed on selected sensitivity elements and their influence on adaptation. Conversely, the implementation of adaptation measures, intentionally or otherwise, affects the sensitivity of the communities analysed and provides the opportunity to build resilience. We found that the interrelation between coping, impact and change triggers the development of adaptation. According to Birkmann (2011), coping as the immediate response and reaction to a hazard comprises all measures that are related to the impact and that are referring to already existing institutional capacities. Conversely, adaptation requires changes in the institutional setting which need time and thus refer to long-term strategies and processes. As our study shows, the tsunami and subsequent coping mechanisms resulted in changing developments in the study areas, which in turn affect the development and initiation of adaptation strategies and processes. We can see that adaptation is a complex iterative process which can be analysed effectively by applying the concept of vulnerability.

In this paper, we focused on the sensitivity and on selected adaptation strategies of the two communities of Ban Nam Khem and Khao Lak. We identified social networks as one key factor contributing to the sensitivity, as they had a positive effect on people's capacity to cope with the tsunami and to adapt in the long run. Other underlying factors include income diversification and the diverse environment in the study areas which helped to cope with income losses. A high income level in combination with a high level of education also decreased the vulnerability. This allows for a quick recovery and enables people to find a new job easily in case of a tsunami-induced job loss. Financial assets in terms of savings and insurance are important in the rebuilding phase, and thus vulnerability-reducing. This corroborates results from other research related to tsunami vulnerability (e.g. Silva and Yamao, 2007; Birkmann and Fernando, 2008; Willroth et al., 2011). The analysed sensitivity elements are shown in Table 2.

In the following, the interrelation of coping, adaptation, impact, and change is underpinned with empirical results. For the community of Ban Nam Khem, a more traditionally shaped community, the impact of the tsunami can be considered a positive starting point for the future development in terms of successful adaptation. The community, which had been an inward migration community before, developed a stronger social cohesion by sharing the experience of overcoming the tsunami and rebuilding the community. Therefore, it can be clearly seen that the sensitivity element "social networks", which emerged during the coping period and which has been further developed since, was very important for the development of adaptation strategies and processes and thus has reduced the vulnerability. In the TRAIT household survey, several persons stated that the community cohesion had been strengthened after the tsunami but that there had been negative impacts in connection with adaptation strategies and processes too. For instance, newly formed neighbourhoods created by the rebuilding of residential buildings in safer areas, in which the population was redistributed, conflict a strengthening of community networks. Such negative impacts very often accompany adaptation strategies and processes and are called adaptation constraints. They often lead to second order adaptation (Adger et al., 2009; Birkmann, 2011). In this example, the external influence on vulnerability can be seen, which is emphasized by Martin (2010).

Many reasonable adaptation strategies developed in Ban Nam Khem, such as community-based disaster management or the replanting of mangroves, which were only possible because of a new spirit within the community and the strengthening of social networks caused by the tsunami and the common experiences during the recovery period. We argue that without a strong social cohesion, adaptation strategies on the community level would not be efficient or would not be developed at all. Hence, further adaptive development must build on strong social networks. Another expression of the new community spirit is the implementation of a communitybased tourism project. Not only the planning of this but also the building process is carried out by the villagers. The community could benefit twice by further increasing the social cohesion through the experience of a conjointly finished 
Table 2. Adaptation strategies: the influence of sensitivity elements and possible consequences.

\begin{tabular}{|c|c|c|}
\hline Pre-Tsunami & Adaptation strategy & Possible consequences \\
\hline \multicolumn{3}{|l|}{ Ban Nam Khem } \\
\hline $\begin{array}{l}\text { Sensitivity elements: } \\
\text { - Social networks } \\
\text { - Income diversification } \\
\text { - Education and income level } \\
\text { Economic focus: } \\
\text { - Fishery and agriculture }\end{array}$ & $\begin{array}{l}\text { Extended social cohesion led to various self- } \\
\text { organised strategies like community-based dis- } \\
\text { aster risk reduction (tsunami drill, replanting } \\
\text { mangroves, etc.) and community-based tourism } \\
\text { projects }\end{array}$ & $\begin{array}{l}\text { - Fostering community cohesion } \\
\text { - Implementation of further } \\
\text { mitigation activities developed } \\
\text { by the community } \\
\text { - Medium increase in income, } \\
\text { followed by an increase in } \\
\text { education } \\
\text { - Diversification of income } \\
\text { sources as long as tourism does } \\
\text { not displace other activities }\end{array}$ \\
\hline \multicolumn{3}{|l|}{ Khao Lak } \\
\hline $\begin{array}{l}\text { Sensitivity elements: } \\
\text { - Social networks } \\
\text { - Income diversification } \\
\text { - Education and income level } \\
\text { Economic focus: } \\
\text { - Tourism and related activities }\end{array}$ & $\begin{array}{l}\text { Change to adapted, nature-oriented tourism } \\
\text { (building codes, focusing on return guests, etc.) }\end{array}$ & $\begin{array}{l}\text { - Increase in income, followed by } \\
\text { an increase in education } \\
\text { - Displacement of traditional } \\
\text { activities; alternatively } \\
\text { maintaining them as a tourist } \\
\text { attraction } \\
\text { - Weakening of community } \\
\text { cohesion } \\
\text { - Decrease of income } \\
\text { diversification }\end{array}$ \\
\hline
\end{tabular}

project and by diversifying the income sources in the community. We argue that income diversification helps the local population in building resilience. Nevertheless, a concentration on the tourism sector and a turning away from traditional activities such as agriculture and fisheries leads to a one-sided dependency and thus increases vulnerability. This can be illustrated in Khao Lak, where the economic focus on tourism resulted in a very long recovery time due to the fact that the majority of tourists avoided the Andaman Coast for years. Furthermore, the lack of diversification manifested itself in insufficient income sources (Calgaro and Lloyd, 2008; Ichinosawa, 2006; Willroth et al., 2011).

The local tourism business owners have attempted to tackle this vulnerable situation in Khao Lak in order to build resilience. They have developed the adaptation strategy of focusing on high income, nature-oriented guests. The problem of limited income diversification has not been approached, but the idea behind that specific strategy is to achieve a higher number of return guests who, on the one hand, have a high spending power and, on the other hand, are more likely to return faster after an event due to their knowledge about the area's situation and an emotional linkage (Kasperson et al., 2004). This corroborates with Rittichainuwat (2006), who discovered for the Phuket province that, after the tsunami, the first returning guests were repeat travellers. Another positive aspect of a strong tourism development is an increase in the income level, which rises parallel to the expenditures of the visitors. We can summarise that Khao Lak still focuses on tourism, but in a more adapted and nature-oriented way. A negative aspect of this strategy is an increased land consumption along the coastline and a displacement of traditional communities accordingly. This forces the displaced fisherman into "second-order adaptation" (Birkmann, 2011) by commuting to their workplaces or hiring guards to protect their equipment. In the long run, the consequence is an even more mono-structured economy without income diversification possibilities. Furthermore, the growing job market in this area attracts a high number of workers. This inward migration leads to a more unstable situation in the community and reduces the social cohesion, which consequently influences the vulnerability negatively.

It can be summarised that the development of adaptation strategies is a complex process in which many factors have to be considered. According to our findings, a deeper awareness and consideration of the underlying sensitivity elements of Ban Nam Khem's and Khao Lak's vulnerability 
is crucial for the implementation of successful adaptation strategies. Our results, in combination with the conceptual considerations, have the following implication: an improved understanding of sensitivity elements can convey appropriate resilience building in terms of effective adaptation strategies. This implies the development of an integrated vulnerabilityadaptation model including loopbacks to assess the change in vulnerability determined by the adaptation strategies undertaken and the consideration of all influencing sensitivity elements. Concrete measures to enhance resilience have to be theoretically elaborated and contextual. Hence, they have to be tailored especially to the pre-existing conditions and the level of the hazard. In this regard, it is important to discuss the application of measures to strengthen social cohesion or to enhance income diversification or other sensitivity elements which can lead to successful adaptation against the background of the research presented here. Only if this has been done properly, the principle "building back better" (Clinton, 2006) can be achieved.

Acknowledgements. The research presented in this paper builds upon the project "Tsunami Risks, Vulnerability and Resilience in the Phang-Nga and Phuket Provinces, Thailand" funded by the German Research Council. This project had a close partner project funded by the National Research Council of Thailand. The survey and focus group interview data used in this research were gathered in close collaboration with Dr. Narumon Arunotai and her team from Chulalongkorn University Social Research Institute. We gratefully acknowledge the constructive feedback from the two reviewers.

Edited by: K. Schwarzer

Reviewed by: two anonymous referees

\section{References}

Adger, W. N.: Vulnerability: Resilience, Vulnerability, and Adaptation: A Cross-Cutting Theme of the International Human Dimensions Programme on Global Environmental Change, Global Environ. Chang., 16, 268-281, http://www.sciencedirect.com/science/article/ B6VFV-4KFMM81-2/2/22ffaffffa0ef5f8451decd3ed9240c3, 2006.

Adger, W. N., Dessai, S., Goulden, M., Hulme, M., Lorenzoni, I., Nelson, D. R., Naess, L. O., Wolf, J., and Wreford, A.: Are there social limits to adaptation to climate change?, Climatic Change, 93, 335-354, doi:10.1007/s10584-008-9520-z, 2009.

Bechteler, A., Pilkama A., Permana E., Poellath J., Prasanai K., Rahaju S., Pessala S., and Alam S. A., eds.: Coastal Zone Management in Southeast Asia. Case: Mangroves and Tsunami effects in Thailand: Report for ME 451: Tropical Forest Landscape Restoration in Southeast Asia, 2006.

Berkes, F., Colding, J., and Folke, C.: Navigating social-ecological systems: Building resilience for complexity and change, Cambridge University Press, Cambridge and New York, http://site. ebrary.com/lib/academiccompletetitles/home.action, 2003.
Birkmann, J.: Measuring vulnerability to promote disaster-resilient societies: Conceptual frameworks and definitions, in: Measuring vulnerability to natural hazards, edited by: Birkmann, J., 9-54, United Nations Univ. Press, Tokyo, 2006.

Birkmann, J.: First- and second-order adaptation to natural hazards and extreme events in the context of climate change, Nat Hazards, doi:10.1007/s11069-011-9806-8, 2011.

Birkmann, J. and Fernando, N.: Measuring revealed and emergent vulnerabilities of coastal communities to tsunami in Sri Lanka, Disasters, 32, 82-105, doi:10.1111/j.1467-7717.2007.01028.x, 2008.

Blaikie, P., Cannon, T., Davis, I., and Wisner, B.: At risk: Natural hazards, people's vulnerability, and disasters, Routledge, London and and New York, 1994.

Bohle, H.-G.: Vulnerability and criticality: perspective from social geography, IHDP Update, 1-7, 2001.

Bohle, H. G. and Glade, T.: Vulnerabilitätskonzepte in Sozialund Naturwissenschaften, in: Naturrisiken und Sozialkatastrophen, edited by Felgentreff, C. and Glade, T., 99-119, Spektrum Akademischer Verlag, Berlin, 2007.

Calgaro, E.: Paradise in Tatters: An Analysis of the Vulnerability of the Tourism Community of Khao Lak, Thailand, to the 2004 Indian Ocean Tsun, 2005.

Calgaro, E. and Lloyd, K.: Sun, sea, sand and tsunami: examining disaster vulnerability in the tourism community of Khao Lak, Thailand, Singapore J. Trop. Geo., 29, 288-306, doi:10.1111/j.1467-9493.2008.00335.x, 2008.

Clark, W., Jaeger, J., Corell, R., Kasperson, R., McCarthy, J., Cash, D., Cohen, S., Desanker, P., Dickson, N., Epstein, P., Guston, D., Hall, J., Jaeger, C., Janetos, A., Leary, N., and Levy, M.: Assessing Vulnerability to Global Environmental Risks, http://belfercenter.ksg.harvard.edu/publication/2767/ assessing_vulnerability_to_global_environmental_risks.html, 2000.

Clinton, W. J.: Lessons Learned from Tsunami Recovery: Key Propositions for Building Back Better, United Nations SecretaryGeneral's Special Envoy for Tsunami Recovery, New York, 2006.

Cutter, S. L., Boruff, B. J., and Shirley, W. L.: Social Vulnerability to Environmental Hazards*, Soc Sci Quart, 84, 242-261, doi:10.1111/1540-6237.8402002, 2003.

DFID: Sustainable Livelihoods Guidance Sheets, 2001.

Gallopín, G. C.: Linkages between vulnerability, resilience, and adaptive capacity, Global Environ. Chang., 16, 293-303, doi:10.1016/j.gloenvcha.2006.02.004, 2006.

Holling, C. S.: Understanding the Complexity of Economic, Ecological, and Social Systems, Ecosystems, 4, 390-405, doi:10.1007/s10021-001-0101-5, 2001.

Ichinosawa, J.: Reputational disaster in Phuket: the secondary impact of the tsunami on inbound tourism, Disaster Prevention and Management, 15, 111-123, 2006.

Kaplowitz, M.: Assessing mangrove products and services at the local level: the use of focus groups and individual interviews, Landscape Urban Plan., 56, 53-60, doi:10.1016/S01692046(01)00170-0, 2001.

Kasperson, J. X., Kasperson R. E., and Turner B.L: Vulnerability of coupled human-ecological systems to global environmental change, in: Human footprints on the global environment, edited by: Rosa, E. A., 231-294, MIT Press, Cambridge and Mass, 
2010.

Kasperson, R. E., Jhaveri, N., and Kasperson, J. X.: Stigma and the social amplification of risk: toward a framework of analysis, in: Risk, media, and stigma, edited by: Flynn, J., Slovic, P., and Kunreuther, H., 9-27, Earthscan, London and and Sterling (Va.), 2004.

Martin, R.: Roepke Lecture in Economic Geography-Rethinking Regional Path Dependence: Beyond Lock-in to Evolution, Econ. Geogr., 86, 1-27, doi:10.1111/j.1944-8287.2009.01056.x, 2010.

Massmann, F.: Analyse der Vulnerabilität von Landwirtschaft und Fischerei an der Andamanküste Thailands im Kontext des Tsunamis von 2004, 2010.

Miller, F., Osbahr, H., Hinkel, J., Downing, T., Folke, C., Nelson, D., Boyd, E., Thomalla, F., Bharwani, S., Ziervogel, G., Walker, B., Birkmann, J., van der Leeuw, S., and Rockström, J.: Resilience and vulnerability: Complementary or conflicting concepts?, http://hdl.handle.net/1959.14/104696, 2010.

NESDB: Gross Regional and Provincial Products 2008p1, 2011.

Nidhiprabha, B.: Adjustment and Recovery in Thailand Two Years after the Tsunami, http://www.adbi.org/files/dp72.thailand. tsunami.adjustment.re\%covery.pdf, 2007.

Pelling, M.: The vulnerability of cities: Natural disasters and social resilience, Earthscan, London, 2003.

Phaphavasit, N., Aksornkoae, S., and Silva, J. d.: Tsunami Impact on Mangrove Ecosystems, Nonthaburi, 2009.

Rittichainuwat, B. N.: Tsunami Recovery: A Case Study of Thailand's Tourism, Cornell Hotel Rest A, 47, 390-404, doi:10.1177/0010880406289994, 2006.

Römer, H., Willroth, P., Kaiser, G., Vafeidis, A. T., Ludwig, R., Sterr, H., and Revilla Diez, J.: Potential of remote sensing techniques for tsunami hazard and vulnerability analysis - a case study from Phang-Nga province, Thailand, Nat. Hazards Earth Syst. Sci., 12, 2103-2126, doi:10.5194/nhess-12-21032012, 2012.

Segschneider, K. and Krause, L.: Bridging the Expectation Gap Empowering Communities in post-disaster governance, Chiang Mai, http://www.c2taw.org/, 2008.

Silva, D. D. and Yamao, M.: Effects of the tsunami on fisheries and coastal livelihood: a case study of tsunami-ravaged southern Sri Lanka, Disasters, 31, 386-404, doi:10.1111/j.14677717.2007.01015.x, 2007.

Smit, B. and Wandel, J.: Adaptation, adaptive capacity and vulnerability, Global Environ Chang, 16, 282-292, doi:10.1016/j.gloenvcha.2006.03.008, 2006.

TAT: Internal Tourism in Phang-Nga 2003-2004, 2005a.

TAT: Tourism in Thailand 2003-2004, 2005b.

TAT: Internal Tourism in Phang-Nga 2005-2006, 2007a.

TAT: Internal Tourism in Phuket 2005-2007, $2007 \mathrm{~b}$.

TAT: Internal Tourism in Phang-Nga 2007-2008, 2009a.

TAT: Tourism in Thailand 2007-2008, 2009b.
Thanawood, C., Yongchalermchai, C., and Densrisereekul, O.: Effects of the December 2004 Tsunami and Disaster Management in southern Thailand, Sci. Tsunami Hazards, 24, 206, http: //tsunamisociety.org/243thana.pdf, 2006.

Thomalla, F., Downing, T., Spanger-Siegfried, E., Han, G., and Rockström, J.: Reducing hazard vulnerability: towards a common approach between disaster risk reduction and climate adaptation, Disasters, 30, 39-48, doi:10.1111/j.14679523.2006.00305.x, 2006.

Turner, B. L., Kasperson, R. E., Matson, P. A., McCarthy, J. J., Corell, R. W., Christensen, L., Eckley, N., Kasperson, J. X., Luers, A., Martello, M. L., Polsky, C., Pulsipher, A., and Schiller, A.: A framework for vulnerability analysis in sustainability science, P Natl Acad Sci USA, 100, 8074-8079, doi:10.1073/pnas.1231335100, 2003.

Vorlaufer, K.: Der Tsunami und seine Auswirkungen in Thailand (Teil 1), Geographische Rundschau, 4, 14-17, 2005.

Willroth, P.: Quantitative vulnerability assessment for economic systems: vulnerability and the process of recovery for households and companies in Phang-Nga and Phuket Provinces in Thailand, vol. 3407 of Europäische Hochschulschriften: Reihe 5, Volksund Betriebswirtschaft, Lang, Frankfurt and M., 2012.

Willroth, P., Revilla Diez, J., and Arunotai, N.: Modelling the economic vulnerability of households in the Phang-Nga Province (Thailand) to natural disasters, Nat. Hazards, 58, 753-769, doi:10.1007/s11069-010-9635-1, 2011.

Wisner, Ben; Blaikie, P. and Cannon, T.: At risk: Natural hazards, people's vulnerability and disasters, Routledge, London, 2 edn., 2005.

Wolfe, D. A.: The strategic management of core cities: Path dependence and economic adjustment in resilient regions, Cambridge Jnl Regions, Econ. Soc., 3, 139-152, doi:10.1093/cjres/rsp032, 2010.

Yamin, F., Rahman, A., and Huq, S.: Vulnerability, Adaptation and Climate Disasters: A Conceptual Overview, IDS Bull, 36, 1-14, doi:10.1111/j.1759-5436.2005.tb00231.x, 2005.

Ziervogel, G., Bharwani, S., and Downing, T. E.: Adapting to climate variability: Pumpkins, people and policy, Nat Resour Forum, 30, 294-305, doi:10.1111/j.1477-8947.2006.00121.x, 2006.

Zou, L.-L. and Wei, Y.-M.: Driving factors for social vulnerability to coastal hazards in Southeast Asia: results from the metaanalysis, Nat. Hazards, 54, 901-929, doi:10.1007/s11069-0109513-x, 2010. 